\title{
Comparison of the Phytochemical and Nutritional Properties of Leaf, Stem and Root of Spondias mombin L.
}

\author{
Nsor Odo Alobi ${ }^{1}$, Godwin Asuquo Bassey ${ }^{1}$, Randymay Eja Kalu² and \\ Kingsley Hovana Enyi-Idoh ${ }^{3}$ \\ ${ }^{1}$ Department of Chemical Sciences, Cross River University of Technology, \\ Calabar, Cross River State, Nigeria \\ ${ }^{2}$ Federal Medical Centre, Yenogoa, Bayelsa State, Nigeria \\ ${ }^{3}$ Department of Microbiology, University of Calabar, Calabar, Cross River State, Nigeria \\ *Corresponding author
}

A B S T R A C T

Some studies have been carried out to examine the phytochemical and nutritional properties of several plants in South-South Nigeria, but relatively none has compared these properties in leaf, stem and root of any of the plants. This study was aimed at comparing the photochemical and nutritional compositions of the leaf, stem and root of Spondias mombin. The leaf, stem and root were processed and analysed for proximate values

Keywords

Spondias, Comparison, Phytochemical, Medicinal, nutritional.

\section{Article Info}

Accepted:

14 May 2017 Available Online: 10 June 2017 (moisture, ash, fat, protein, fibre and carbohydrate), minerals ( $\mathrm{Na}, \mathrm{K}, \mathrm{Ca}, \mathrm{Fe}, \mathrm{Mg}, \mathrm{Mn}$ and $\mathrm{P}$ ), vitamins (A, B1, C, D and E) and phytochemical properties (alkaloids, flavonoids, saponins and tannins) using standard methods. Results showed that the root was richest in moisture $(35.78+0.31 \%)$ followed by the leaf $(32.59+0.08 \%)$ which is also richest in carbohydrate $(32.08+0.66 \%)$. The stem was richest in ash $(24.52+0.20 \%)$. The leaf, stem and root each had more than $2 \mathrm{mg} / 100 \mathrm{ml}$ of vitamin B1 and more $1 \mathrm{mg} / 100 \mathrm{ml}$ of vitamin C. For both proximate values and vitamins, there was a significant difference $(\mathrm{P}<0.05)$ between the leaf, stem and root. Regarding mineral and phytochemical properties, there was no significant difference $(\mathrm{P}>0.05)$ between the leaf, stem and root. The mineral contents for leaf and stem were respectively richest in $\mathrm{K}(8.61+0.20 \mathrm{mg} / \mathrm{l}, 8.68+0.10 \mathrm{mg} / \mathrm{l}$, while the leaf and stem were richest in $\mathrm{Na}(4.52+0.20 \mathrm{mg} / \mathrm{ml}$ and $4.21+0.20 \mathrm{mg} / 1$ respectively). The stem was richest in alkaloids $(3.40+0.20 \mathrm{mg} / 100 \mathrm{ml})$ and saponins $(4.30+0.8 \mathrm{mg} / 100 \mathrm{ml})$ while the leaf was richest in flavonoids $(3.10+0.20 \mathrm{mg} / 100 \mathrm{ml})$. The leaf was also richest in tannins $(0.80+0.09 \mathrm{mg} / 100 \mathrm{ml})$, indicating that different parts of the plant have different medicinal properties. In conclusion, the leaf, stem and root of the plant have different phytochemical and nutritional properties and will individually be effective for different uses. It was found that the plant contains pyhtochemicals of medical importance and therefore can be used medicinally.

\section{Introduction}

Spondias mombin L. is a vascular plant found in the Cross River National Park, South-South Nigeria and some other West African countries, e.g., Ghana (Schmitt, 1996).
It is not only found in the Oban Division of the National Park, but also found in other parts of Cross River State. The plant is in the family Anacardiaceae and its common name 
is hog plum. The medicinal and nutritional significance of $S$. mombin L. is not clear, but the local population regards it and takes it as medicine for various ailments including gastroenteritis and rheumatism. Some people use the extract of the leaf, and some grind the bark and root of the plant for the treatment of different ailments.

Research is on-going on the medicinal plants found in this part of the world (Alobi et al., 2012; Ikpeme et al., 2013; Alobi et al., 2015). Some of the researches investigate the phytochemical and nutritional composition of plants to confirm their medicinal potential and their aid in the physiological functioning of the body. Puranik et al., (2012) report that the beneficial medicinal effect of plant materials typically results from the combinations of secondary metabolites such as alkaloids, steroids, tannins, phenolic compounds, flavonoids, resins, fatty acids and gums. Some parts of plant origin, e.g., the leaves, may contain bioactive compounds and thus serve as an important source of minerals, vitamins and certain hormone precursors in addition to protein and energy sources (Cho et al., 2004; Puranik et al., 2012).

Within African communities and other communities across the world, it is an established fact that not all parts of some plants are medicinally and nutritionally relevant. For instance, the people of Cross River State of Nigeria, specifically people from Yakurr Local Government Area, use the extract from the stem of Cissus aralioides (Planch) in the family Ampelidaceae and locally called Kotolokom by Yakurr people, to treat rheumatism and swellings. On the other hand, they use the liquid extract from the leaves for the treatment of pneumonia and bronchial asthma in children. Also, the aerial part of Telfairia occidentalis in the family Cucurbitaceae, is edible and the leaves used for soup, but the root is highly toxic and poisonous.
The aim of this study, therefore, was to analyse the leaf, stem and root of S. mombin L. for phytochemical and nutritional properties and compare them to know the medicinal and nutritional relevance of each part of the plant.

\section{Materials and Methods}

\section{Source of test plant}

The plant whose leaf, stem and root were analysed, was harvested from the Staff /Quarters of Cross River University of Technology, and carried to the herbarium of the same University for identification as Spondias mombin $\mathrm{L}$.

\section{Preparation of the leaf, stem and root extracts of the plant}

The leaf of the plant was air-dried under controlled conditions to avoid chemical changes in the material. The drying was done quickly at low temperature (Harley and Bell, 1967). The stem and root were air-dried and chopped into pieces and separately ground in a mortar.

The extracts were prepared (Mukhtar and Tukur, 2000) by transferring the powdered sample $(50 \mathrm{~g})$ into a sexhlet apparatus which had a condenser attached at the top. The vapour from the solvent reached the soxhlet through the side tube and condensed on passing into the condenser. The condensed solvent dropped on the plant powder in the timble and dissolved the required substances in the powder. This process continued until the solvent from the timble was colourless. Extraction was then said to be complete, i.e., extraction of all components of the plant that were soluble in ethanol was complete. The residue was retained as crude ethanolic extract for each of leaf, stem and root samples. 


\section{Proximate analysis}

Proximate analyses for moisture, ash, fat, crude protein, fibre and total carbohydrate were carried out in triplicate using the methods as described by AOAC (1990); Nos 930.09, 930.10 and 930.05 were respectively used in analyzing for fat, fibre and ash, while protein was determined using the Leco-N nitrogen determinator (Model FP-428, Leco, Corporate MI, USA). By difference, the nitrogen free extractive (NFE) was obtained. The moisture content was obtained by drying the sample to a constant weight in an air circulating oven at $70-90^{\circ} \mathrm{C}$. Total hydrocarbon was determined as the remainder after accounting for ash, crude fibre, protein and fats.

\section{Mineral analysis}

The mineral elements (K, Ca, Fe, Mg, Mn, P) were determined using a Pye Unicam Sp9 atomic absorption spectrophotometer (Pye Unicam Ltd., York Street, Britain). Using regressing equations (Miller and Miller, 1986), the levels of metals in each sample were calculated using their absorbance and dilutions.

\section{Vitamin analysis}

The methods of AOAC (1990) were used in the determination of vitamins. Each of the extracts $(2.0 \mathrm{mls})$ was placed in a test tube, followed by one drop of isopropanol and a drop of concentrated $\mathrm{H}_{2} \mathrm{SO}_{4}$ and allowed to digest. With U.V vis spectrophotometer, the level of vitamin A was measured at a wavelength of $325 \mathrm{~nm}$. The same treatment was given to the standard vitamin $\mathrm{A}$. To measure vitamin B1, 5\% diazophenyl sulphuric acid is added to $0.5 \mathrm{ml}$ of each of the extracts and allowed for some time for colour development before being measured with U.V vis spectrophotometer at the wavelength of $550 \mathrm{~nm}$.
The method of Puranik et al., (2012) was used in determining vitamin $\mathrm{C}$. Using the method involves digesting $5 \mathrm{~g}$ of each of the dried sample in concentrated $\mathrm{HNO}_{3}$ which is quantitatively transferred to a $50 \mathrm{ml}$ volumetric flask and made up to volume with distilled water (Puranik et al., 2012). A blank digest was treated the same. Both digests were measured with U.V. vis spectrophotometer at $550 \mathrm{~nm}$.

For vitamin D, 5 drops of the extract were added to a test tube containing 10 drops of aniline reagent. The mixture was boiled for 30 minutes for colour development. The absorbance using vis spectrophotometer at a wavelength of $550 \mathrm{~nm}$ was measured. The same treatment was made on the standard.

To measure vitamin E, 2 drops of concentrated $\mathrm{HNO} 3$ and $5 \mathrm{ml}$ of distilled water were added to $0.5 \mathrm{ml}$ of each of the extracts. This was shakened and allowed for colour development before measuring absorbance with U.V. vis spectrophotometer at a wavelength of $600 \mathrm{~nm}$. The same treatment was given to the standard (AOAC,1990).

\section{Phytochemical analysis}

A quantitative phytochemical compositions of the leaf, stem and root of the plant were assessed using the methods of Trease and Evans (1989), Sofowora (1993) and Harbone (1998). The phytochemical components were alkaloids, flavonoids, saponins and tannins.

\section{Statistical analysis}

Statistical analysis of the data was carried out using analysis of variance (ANOVA) (Miller and Miller, 1986).

\section{Results and Discussion}

Results of analysis for proximate values, minerals, vitamins and phytochemical 
composition are shown in tables $1-4$. The root was richest in moisture $(35.78+0.31 \%)$ followed by the leaf $(32.59+0.08 \%)$. The stem was richest in ash $(24.52+0.20 \%)$ while the leaf was richest in carbohydrate $(32.08+0.66 \%)$ Fat, crude protein and fibre were highest in the root. There was a significant difference $(\mathrm{P}<0.05)$ between the leaf, stem and root with respect to the levels of proximate compositions. There was no significant difference $(\mathrm{P}>0.05)$ in mineral content between the leaf, stem and root. The stem was slightly richest in $K$ $(0.68+0.10 \mathrm{mg} / \mathrm{l})$ followed by the leaf $(8.61+0.20 \mathrm{mg} / \mathrm{l})$ while the leaf was slightly richest in $\mathrm{Na}(4.52+0.20 \mathrm{mg} / \mathrm{l})$ followed by the stem $(4.21+0.20 \mathrm{mg} / \mathrm{l})$.

The leaf, stem and root revealed relatively high content of vitamin B1 $(2.45+0.20$, $2.56+0.20$ and $2.28+0.30 \mathrm{mg} / 100 \mathrm{ml}$ respectively), followed by vitamin $\mathrm{C}$ $(1.38+0.10, \quad 1.42+0.10 \quad$ and $1.48+0.10 \mathrm{mg} / 100 \mathrm{ml}$ respectively). There was significant difference $(\mathrm{P}<0.05)$ between the leaf, stem and root.

The phytochemical composition revealed no significant difference ( $\mathrm{P}>0.05)$ between leaf, stem and root. Potentially, however, the leaf, stem and root are of medicinal significance since all possess bioactive substances. The stem was richest in alkaloids $(3.40+0.20 \mathrm{mg} / 100 \mathrm{ml})$ while the leaf was richest in flavonoids $(3.10+0.20 \mathrm{mg} / 100 \mathrm{ml})$. The stem was also richest in saponins $(4.30+0.08 \mathrm{mg} / 100 \mathrm{ml})$ while the leaf was richest in tannins $(0.80+0.09 \mathrm{mg} / 100 \mathrm{ml})$.

The phytochemical and nutritional profiles of leaf, stem and root of Spondias mombin revealed that all parts of the plant were of potential medicinal and nutritional significance. This could be the reason why some people in South-South Nigeria drink the leaf extract as a remedy for gastroenteritis and some other ailments. Even the bark of the stem is boiled and the filtrate is taken as medicine (Otu, 2015).

In this study, the leaf was richest in Flavonoids $\quad(3.10+0.20 \mathrm{mg} / 100 \mathrm{ml}$ extract $)$ while the stem was richest in Alkaloids $(3.40+0.20 \mathrm{mg} / 100 \mathrm{ml}$ of extract), and Saponins $(4.30+0.08 \mathrm{mg} / 100 \mathrm{ml})$ followed by the root with Saponins $(3.10+0.03 \mathrm{mg} / 100 \mathrm{ml})$ which was equally high. Further, the level of tannins $(0.80+0.09 \mathrm{mg} / 100 \mathrm{ml}$ was highest in the leaf. The phytochemical composition shows no significant difference $(\mathrm{P}>0.05)$ between leaf, stem and root. These bioactive compounds are of significance medically. Alkaloids in particular, possess antimicrobial properties, prevent nocturnal leg cramps caused by vascular spasms and used to treat gastrointestinal complaints (Puranik et al., 2012; Alobi et al., 2013). Tannins draw the tissues together and help to improve resistance to infection (Puranik et al., 2012).

This study further revealed that there was significant difference $(\mathrm{P}<0.05)$ between leaf, stem and root with respect to proximate values. The leaf was richest in carbohydrate $(32.08+0.66 \%)$, the stem richest in ash $(24.52+0.20 \%)$, while the root was richest in moisture content $(35.78+0.31 \%)$, indicating that different parts of the plant may have differences in nutritional profiles. Moreover, from the high levels of proximate values, the plant was noted to be of high nutritional significance (Alobi et al., 2013). Also, most plants taken as food by man have proximate ash, crude fat, protein, fibre and carbohydrate (Udosen et al., 1999; Okwu, 2001; Atang who et al., 2009; Alobi et al., 2012). 
Int.J.Curr.Microbiol.App.Sci (2017) 6(6): 804-810

Table.1 Proximate values of Spondia mombin

Plant part Proximate values

\begin{tabular}{lllllll} 
& Moisture & Ash & Fat & $\begin{array}{l}\text { Crude } \\
\text { protein }\end{array}$ & Fibre & $\begin{array}{l}\text { Total } \\
\text { carbohydrate }\end{array}$ \\
\hline Leaf & $32.59 \pm 0.08$ & $19.83 \pm 0.05$ & $2.79 \pm 0.20$ & $3.91 \pm 0.30$ & $8.32 \pm 0.50$ & $32.08 \pm 0.66$ \\
Stem & $27.88 \pm 0.11$ & $24.52 \pm 0.20$ & $3.11 \pm 0.20$ & $4.70 \pm 0.30$ & $8.81 \pm 0.42$ & $31.29 \pm 0.60$ \\
Root & $35.78 \pm 0.31$ & $22.28 \pm 0.20$ & $4.43 \pm 0.20$ & $4.97 \pm 0.10$ & $8.97 \pm 0.40$ & $27.79 \pm 0.70$ \\
\hline
\end{tabular}

Table.2 Mineral elements of Spondias mombin

\begin{tabular}{llllllll}
\hline Plant part & \multicolumn{7}{l}{ plant mineral elements $(\mathrm{mg} / \mathrm{l})$} \\
& $\mathrm{Na}$ & $\mathrm{K}$ & $\mathrm{Ca}$ & $\mathrm{Fe}$ & $\mathrm{Mg}$ & $\mathrm{Mn}$ & $\mathrm{P}$ \\
\hline Leaf & $4.52 \pm 0.20$ & $8.61 \pm 0.20$ & $2.63 \pm 0.10$ & $4.25 \pm 0.10$ & $0.02 \pm 0.00$ & $1.44 \pm 0.10$ & $1.60 \pm 0.40$ \\
Stem & $4.21 \pm 0.20$ & $8.68 \pm 0.10$ & $2.42 \pm 0.10$ & $4.08 \pm 0.40$ & $0.03 \pm 0.02$ & $0.16 \pm 0.10$ & $1.65 \pm 0.10$ \\
Root & $4.10 \pm 0.40$ & $8.58 \pm 0.20$ & $2.83 \pm 0.10$ & $3.90 \pm 0.20$ & $0.02 \pm 0.04$ & 1.62 & $1.5 \pm \pm 0.01$ \\
\hline
\end{tabular}

Table.3 Vitamin composition of Spondias mombin

\begin{tabular}{llllll}
\hline Plant part & \multicolumn{5}{l}{ plant vitamins $(\mathrm{mg} / 100 \mathrm{ml})$} \\
\cline { 2 - 6 } & Vit. A & Vit. $\mathrm{B}_{1}$ & Vit. C & Vit. D & Vit. E \\
\hline Leaf & $0.026 \pm 0.00$ & $2.45 \pm 0.20$ & $1.38 \pm 0.10$ & $0.005 \pm 0.00$ & $0.35 \pm 0.02$ \\
Stem & $0.062 \pm 0.00$ & $2.56 \pm 0.20$ & $1.42 \pm 0.10$ & $0.005 \pm 0.06$ & $0.37 \pm 0.00$ \\
Root & $0.047 \pm 0.00$ & $2.28 \pm 0.30$ & $1.48 \pm 0.10$ & $0.006 \pm 0.00$ & $0.38 \pm 0.80$ \\
\hline
\end{tabular}

Table.4 Phytochemical analysis of the extracts of Spondias mombin

\begin{tabular}{lllll}
\hline Plant part & \multicolumn{4}{l}{ plant phytochemical properties $(\mathrm{mg} / 100 \mathrm{ml})$} \\
\cline { 2 - 5 } & Alkaloids & Flavonoids & Saponin & Tannin \\
\hline Leaf & $1.3 \pm 0.02$ & $3.10 \pm 0.20$ & $2.80 \pm 0.10$ & $0.80 \pm 0.09$ \\
Stem & $3.40 \pm 0.20$ & $2.5 \pm 0.10$ & $4.30 \pm 0.08$ & $0.47 \pm 0.05$ \\
Root & $1.7 \pm 0.3$ & $1.9 \pm 0.20$ & $3.10 \pm 0.03$ & $0.42 \pm 0.14$ \\
\hline
\end{tabular}

There was equitable distribution of minerals ( $\mathrm{Na}, \mathrm{K}, \mathrm{Ca}, \mathrm{Fe}, \mathrm{Mg}, \mathrm{Mn}$ and $\mathrm{P}$ ) in the leaf, stem and root. There was no significant difference $(\mathrm{P}>0.05)$ between leaf, stem and root. The $\mathrm{Na}$ and $\mathrm{K}$ contents in leaf, stem and root were respectively above 4 and $8 \mathrm{mg} / \mathrm{l}$ of extracts, while $\mathrm{Ca}$ and $\mathrm{Fe}$ contents in leaf, stem and root were above 2 and $3 \mathrm{mg} / \mathrm{l}$ respectively. The phosphorus contents in leaf $(1.44+0.10 \mathrm{mg} / \mathrm{l})$, stem $(1.65+0.10 \mathrm{mg} / \mathrm{l})$ and root $(1.54+01 \mathrm{mg} / \mathrm{l})$ appeared to be above the recommended level (Mobil Report, 1998).
Generally, the mineral contents appeared to be too high and at variance with the results obtained for Cnidoscolus carumbium and Spigella marilandica (Alobi et al., 2013). This indicates that even though the plant is potentially medicinal, it may not be useful to man nutritionally with respect to mineral content.

This study on vitamins (A, B, C, D and E) revealed that vitamins $B$ and $C$ were high in the leaf, stem and root. The leaf, stem and 
root contained 2.45+0.20, 2.56+0.20 and $2.28+0.30 \mathrm{mg} / 100 \mathrm{~m}$ of vitamin B1 respectively, whereas the leaf, stem and root contained $1.38+0.10, \quad 1.42+0.10$ and $1.48+0.10 \mathrm{mg} / 100 \mathrm{~m}$ of vitamin $\mathrm{C}$ respectively. The levels of other vitamins (A, D and E) were relatively low. There was a significant difference $(\mathrm{P}<0.05)$ between the leaf, stem and root. This indicates that the plant can be relied upon for the presence of vitamins B1 and $\mathrm{C}$. It is not surprising that pregnant women in South-South Nigeria drink the raw extract regularly. Puranik et al., (2012) report that sufficient quantity of vitamin C may help to control physiological oxidative stress. Such high levels of vitamins $\mathrm{C}, \mathrm{A}$ and $\mathrm{E}$ have been observed in Gongronema latifolium $(290+0.45 \mathrm{mg} / 100 \mathrm{ml})$ which is taken by many people in South-South Nigeria (Alobi et al., 2015), thus making G. latifolium more preferred from nutritional point of view.

In conclusion, the levels of phytochemical components, proximate values, minerals and vitamins were relatively different in the leaf, stem and root of Spondias mombin, although the differences in the levels of minerals and phytochemical properties might not be significant. Moreover the test plant appeared to be medicinally more potent than nutritionally.

The presence of phytochemicals in S. mombin L. as observed suggests strongly that this plant which use has been established in many parts of the tropical regions of the African continent must have some medicinal properties. In this age and time when the war against bacterial resistance to standard antibiotics seems to be on an onslaught, the need for new and more effective antibacterial alternatives cannot be underestimated. This alternative can only be found in plants, nature's gift to mankind.

In fact, resistance to plant antimicrobials is very rare when the plant is known to have adequate phytochemicals. Incidentally the leaves and stem of $S$. mombin L. have useful quantities of flavonoids and saponins and therefore a good level of antibacterial potentials.

Recommendation for further studies is for the phytochemical components of this plant to be characterized and indexed for a better identification and production potential for use as synthetic antibiotics.

\section{References}

Alobi, N.O., Bassey, G.A., Abara, A.E., Eja, M.E., Enyi-Idoh, K.H., Ikpeme, E.M., Okoi, A.I. 2013. Bioactive and nutritional significance of Cnidoscolus carumbium and Spigella marilandica. Transnational J. Sci. Tech., 3(2): 14-21.

Alobi, N.O., Eja, M.E., Okoi, A.I., Uno, U.A., Asuquo, B.G. 2015. Comparative evaluation of the nutrient compositions of Andrographis paniculata and Gongrolema latifolium. New York Sci. J., 8(12): 16-20.

Alobi, N.O., Ikpeme, E.M., Okoi, A.I., Etim, K.D. and Eja, M.E. 2012. Phytochemical and nutritional profiles of Lasianthera africana and Heinsia crinata and Gongronema latifolium. New York Sci. J., 5(3): 45-48.

AOAC. 1990. Official Methods of Analysis. 15th Ed. Washington, D. C. Association of Official Analytical Chemists.

Atangwho, I.J., Ebong, P.E., Eyong, E.U., Williams, I.O., Eteng, M.U. and Egbung, G.E. 2009. Comparative chemical composition of leaves of some antidiabetic medicinal plants: Azadirachta indica, Vernonia amydalina and Gongronema latifolium. Afr. J. Biotech., 8(18): 4685-4689.

Cho, E., Seddom, J., Ronser, B., Willet, W., Hankison, S. 2004. Prospective study of intake of fruits, vegetables, vitamins 
and carotenoids and related musculopathy. Arch. Opthamol., 122: 883-892.

Harbone, J.B. 1998. Methods of extraction and isolation. In: Phytochemical methods. Chapman and Hall, London, pp. 60-66.

Harley, R. and Bell, M.G. 1967. Plants: Other constituents in official methods of analysis of the associations of official analytical chemists. Nature, 21: 1241.

Ikpeme, E.M., Alobi, N.O., Enyi-Idoh, K.H., Okoi, A.I., Etim, K.D., Eja, M.E. 2013. The phytochemical and antimicrobial studies of Ficus exasperata and Cida acuta on Staphylococcus aureus and Escherichia coli. Central Europ. J. Exp. Biol., 2(2):1-4.

Miller, J.C. and Miller, J.N. 1986. Statistics for Analytical Chemistry. Ellis Horwood, Chichester, 202p.

Mobil Report. 1998. Report of Post Impact Assessment (PIA) of Cross River State coastal areas affected by Mobi (Idoho) oil spills. Deveman consult (Nig.) Ltd., for Government of Cross River State of Nigeria.

Mukhtar, M.D. and Tukur, A. 2000. Biology of Pista stratiotes and its toxicity effects in rats. J. Zoo. Env. Biol., 49(2): 39-49.

Okwu, D.E. 2001. Evaluation of the chemical composition of indigenous spices and flavouring agents. Global J. Pure Appl. Sci., 7: 455-459.

Otu, J.U. 2015. Antimicrobial effect of leaf extracts of Vernonia amygdalina and bark of Magnifera indica on Salmonella species isolated from poultry farms. An M.Sc. project submitted to the Graduate School of Cross River University of Calabar.

Puranik, V., Tripathi, D.K., Kaur, D., Chauham, D.K. 2012. Nutritional evaluation of leaves of Boerhaavia diffusa L. and Andrographis paniculata (Burm. F.) Wall. Exnes: Implication for nutritional applications. Int. J. Pharm. Bio. Sci., 3(4):315-321.

Schmitt, K. 1996. Botanical in the Oban Division, Cross River National Park. Oban Hills Programme, Calabar, p. 151.

Sofowora, A. 1993. Medicinal Plants and Traditional Medicine in Africa. 2nd Ed. John Willey and Sons, New York, pp. 26-105.

Trease, G.E. and Evans, W. 1989. A text of pharmacagnosy. 8th Ed. Bailliere Tindall Ltd. London.

Udosen, E.O., Udok, U.E. and Unuigbe, O.S. 1999. The comparison of the nutrient composition of Lasianthera africana and Heinsia crinata. J. Food Biochem., 23: 571-576.

\section{How to cite this article:}

Nsor Odo Alobi, Godwin Asuquo Bassey, Randymay Eja Kalu and Kingsley Hovana EnyiIdoh. 2017. Comparison of the Phytochemical and Nutritional Properties of Leaf, Stem and Root of Spondias mombin L.. Int.J.Curr.Microbiol.App.Sci. 6(6): 804-810. doi: https://doi.org/10.20546/ijcmas.2017.606.094 